\title{
THE EFFECTIVENESS OF ANIMATION VIDEO TECHNOLOGY IN ARABIC LANGUAGE TEACHING ON STUDENTS OF ISLAMIC ELEMENTARY SCHOOL OF METRO CITY
}

\author{
Akla \\ Institut Agama Islam Negeri Metro \\ Iringmulyo, Metro, Lampung, Indonesia, 34112 \\ E-mail:akla@metrouniv.ac.id

\begin{tabular}{c|c|c}
\hline Received: & Revised: & Approved: \\
23/01/2021 & $05 / 03 / 2021$ & $19 / 04 / 2021$ \\
\hline
\end{tabular} \\ DOI : https:// doi.org/10.32332/akademika.v26i1.3011

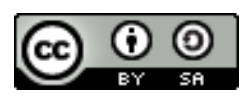 \\ The Effectiveness of Animation Video Technology In Arabic Language Teaching On \\ Students Of Islamic Elementary School Of Metro City Licensed Under a Creative \\ Commons Attribution-ShareAlike 4.0 International License
}

\begin{abstract}
Students' difficulties in learning come from boredom, lack of excitement, and laziness stimulated by monotonous and uninteresting learning. This research aims to analyze three things: (1) how the use of animation video technology takes place in the process of Arabic learning; (2) how the students' learning attitude performs while using animation video technology; and (3) how the effectiveness of the use of animation video technology enhances the students' Arabic language mastery. This research method uses mixed-method research by combining qualitative and quantitative methods, focusing on the data collection and data analysis process. This research's respondents are the students of State Islamic Elementary School of Metro City, Lampung totaling 70 students. The research instrument is the list of questions to gain data on the implementation of learning using the animation video technology. The test instrument to get data about the results of Arabic learning before and after using animation video technology. This study results in findings that animation video technology has created a psychological atmosphere that is fun for the children. The feeling of pleasure has developed students' positive attitude in learning. The results of the $t$-test show that sig (2-tailed) is equal to $0.019<$ the value of a (0.05), which means that there is a significant influence on the use of animation video technology on students' Arabic language ability. This study concludes that animation video technology designed interestingly has overcome various difficulties of students' learning. This study recommends using animation video technology in teaching the Arabic language.
\end{abstract}

Keywords: Animation Video Technology, Learning Attitude, Language Mastery

\section{A. Introduction}

The learning of Arabic language on the students of Islamic elementary school faces various constraints that have an impact on not achieving the learning competency 
set. Some of the obstacles experienced by students come from low passion, a negative attitude in learning that is stimulated by the use of learning media that is not varied and tends to be boring. The study of Abdul Hakim mentions that the use of monotonous learning media causes learning difficulties experienced by students in the form of difficulty in understanding learning materials ${ }^{1}$. Tedious learning creates a sense of boredom and laziness in learning' ${ }^{2}$. Students' difficulty in education is also caused by the learning environment that is not comfortable, which causes students to lack of concentration in learning ${ }^{3}$. Such difficulties have an impact on the low mastery of the Arabic language. Said's report shows that $27 \%$ of students' language ability is at the adequate level, as much as $53 \%$ of the students' language ability is at the low level, and $20 \%$ of it is at the level of very low ${ }^{4}$. Latifah and Aviya indicate the similar report that the results of students' Arabic language learning in Islamic elementary school before cooperative learning applied are that $27 \%$ of students are at the low level, as much as $73 \%$ are at the medium level. No one is at a high level 5 .

The difficulty of the Arabic language learning for Islamic elementary school students was identified from two main problems; the linguistic problems and nonlinguistic problems. The linguistic issues cover the difficulty in determining the meaning of the sound that is heard, difficulty in expressing an opinion, the difficulty in writing Arabic symbols, the difficulty of mastering the vocabulary and difficulty in pronouncing sound. The non-linguistics problems related to students' psychological factors in the form of feeling bored, lazy and not eager in learning and low learning motivation are stimulated by the use of the irrelevant strategy, the lack of learning media on active learning orientation and unconducive learning environment. Besides students' psychological factors, the background of students with a different understanding of the Arabic language, and the inadequate infrastructure in the Arabic language learning become other factors of Arabic learning difficulty.

So far, the study of the Arabic language learning on Islamic elementary school students tends to examine three key issues. First, studies that view the importance of the role of learning strategies in improving the students' language proficiency. The use of varied and fun learning strategies can increase motivation and learning outcomes ${ }^{6}$. Some assess that the presence of the teacher in the learning process influence students'

${ }^{1}$ Muhammad Kamal bin Abdul Hakim, "Multimedia and Critical Thinking on Arabic Guided Writing Learning," Dinamika Ilmu 19, no. 2 (2019): 211-23

2 Muh Barid Nizarudin Wajdi, "Dynamic Learning for the Arabic language," EDUTE : Journal of Education And Technology 2, no. 2 (2019): 25-31.

${ }^{3}$ Natalie H. Brito, "Influence of the Home Linguistic Environment on Early Language Development," Policy Insights from the Behavioral and Brain Sciences 4, no. 2 (2017): 155-62.

4 Rukman AR Said, "Fa'aliyyah Isti'mal al-Wasail al-Sam'iyyah wa al-Mar'iyyah li Tanmiyah Maharah al-Istima' fi Ta'lim al-Lugah al-'Arabiyyah bi al-Madrasah al-Tsanawiyah as-'Adiyah Pengkendekan bi Al-Fashl al-Tsamin fi Luwu al-Syimaliyah," AL IBRAH: Journal of Arabic Languange Education, (2018).

${ }^{5}$ Latifah Latifah dan Nur Aviya, "Pengaruh Model Cooperative Learning Tipe Think Pair Share (TPS) Terhadap Hasil Belajar Siswa pada Pelajaran Bahasa Arab di MI," Al Ibtida: Jurnal Pendidikan Guru MI 5, no. 1 (2018): 83.

${ }^{6}$ Minna Maijala, "Culture teaching methods in foreign language education: pre-service teachers' reported beliefs and practices," Innovation in Language Learning and Teaching 14, no. 2 (2020): 133-49; Fan Wei Kung, "Teaching second language reading comprehension: the effects of classroom materials and reading strategy use," Innovation in Language Learning and Teaching 13, no. 1 (2019): 93-104; Jing Han dan Qingsheng Lu, "A Correlation Study among Achievement Motivation, Goal-Setting and L2 Learning Strategy in EFL Context," English Language Teaching 11, no. 2 (2017): 5. 
learning activities in achieving the learning objectives ${ }^{7}$. Second, studies that view the use of technology media as a mean of support which can increase the concentration of learning. The presence of technology media in the learning process gives a significant influence on the concentration and student learning outcomes. Technology media in education is considered as a tool that can provide an impact on the atmosphere and learning environment created by the teacher so that it can raise the motivation and interest in learning 8 . Motivation and interest in learning can encourage students to master knowledge and skills well. The use of technology media in teaching and learning effectively facilitates teachers in carrying out teaching duties. Third are the studies that examine the influence of technology of video animation toward students' learning outcomes. The use of animation video technology in learning can improve students' understanding of the subject matter that impact on the achievement of learning outcomes ${ }^{9}$. From the three research tendencies, the psychological dimensions of the use of animated video in teaching and learning the Arabic language have not been studied carefully. At the same time, the analysis is less aimed at the age group of the students of elementary school because the studies are focused on a group of intermediate students and the college students.

This study complements the shortcomings of the previous studies that tend to ignore the psychological factors of the students in the use of technology as a learning tool. The use of technology in learning for children at this time becomes an alternative to the problem solving of the low concentration and enthusiasm for learning. This study implicitly describes the process of participative Arabic learning that is based on animation video technology. In line with this objective, three questions can be formulated: (1) how does the use of technology video animation take place in the process of learning Arabic; (2) how is the students' learning attitude while using animation video technology; and (3) how is the effectiveness of the use of animation video technology in the learning of the Arabic language. The answer to this question becomes a discussion that provides an understanding of the potency of animation video technology in resolving the difficulties of learning experienced by students at an elementary school level in learning Arabic.

This paper is based on two arguments. First, the use of animation video technology in teaching and learning can facilitate students in improving Arabic language learning outcomes. The improvement is caused by the use of animation video technology that provides learning space with entertainment for students. The material content of entertaining animation videos can enhance the sense of fun and

7 Andrea Mason dan Caroline Payant, "Experienced teachers' beliefs and practices toward communicative approaches in teaching English as a foreign language in rural Ukraine," TESOL Journal 10, no. 1 (2019): 1-15,; Zhao Hong Han, “Task-Based Learning in Task-Based Teaching: Training Teachers of Chinese as a Foreign Language," Annual Review of Applied Linguistics 38 (2018): 162-86,

8 Scott A. Crossley, "Technological disruption in foreign language teaching: The rise of simultaneous machine translation," Language Teaching 51, no. 4 (2018): 541-52; Jingjing Ruan dan Jane Medwell, "Using social networking technology to develop intercultural communicative competence: a case of GCSE Mandarin," Innovation in Language Learning and Teaching 0, no. 0 (2019): 1-31

${ }_{9}$ Andrew Burn, "Making machinima: animation, games, and multimodal participation in the media arts," Learning, Media and Technology 41, no. 2 (2016): 310-29; Mywish K. Maredia dkk., "Can mobile phone-based animated videos induce learning and technology adoption among low-literate farmers? A field experiment in Burkina Faso," Information Technology for Development 24, no. 3 (2018): 429-60. 
concentration in learning, ultimately improving learning outcomes. Besides, the characteristics of the animation video technology material are in line with the age of elementary school students. Second, the success of Arabic language learning is primarily determined by the students ' learning attitude. A positive attitude in learning can facilitate students in following the learning process and understand the subject matter. Positive behaviours demonstrate a positive attitude in learning in responding to knowledge and becomes a determinant of learning success. Without a positive attitude in education, students cannot do the Arabic language learning process well.

\section{B. The Concept of Language Learning}

Language learning is all the activities designed by the teacher by involving a variety of learning resources to support students in learning the language ${ }^{10}$. Activities in the learning produce behavioral changes in the students. Changes in behavior are either in the form of changes in knowledge or skill changes that are due to the learning experience conducted in a fun environment ${ }^{11}$. A pleasant environment can be constructed in a learning design that is actively supported by the completeness of learning infrastructure ${ }^{12}$. Referring to the concept of behaviorism, the child' skill and knowledge acquisition are as a result of the stimulus that is carried out continuously, which create the response of imitation, association and analogy of the child ${ }^{13}$. The influential students' knowledge and the skills are a response to a stimulus planned. The giving of encouragement continuously causes the answer to be a habit ${ }^{14}$. In the language learning context, the skills that are taught first are the skills of listening and speaking and continued with reading and writing skills ${ }^{15}$. Besides, the learning process is accompanied by giving training of language use actively and continuously in the conducive speaking environment ${ }^{16}$.

However, the theory of nativism says that every child can learn a language from birth, called the language acquisition device. This theory states that language learning is a process of hypothesis formation and not habit formation. The hypothesis formatted in a learning environment will give experience in children in mastering the language ${ }^{17}$. The child's ability to master the language because of the interaction with the environment occurs because every child can master and create expressions based on what is heard and seen $^{18}$. Language acquisition device in children is a language

${ }^{10}$ Kung, "Teaching second language reading comprehension: the effects of classroom materials and reading strategy use.

11 Rebecca L Oxford, "Language Learning Styles and Strategies-Concepts and Relationships-Oxford, Book, (2003): 271-78.

12 Bonnie Higgins dan Helen Reid, "Enhancing 'Conceptual Teaching/Learning' in a Concept-Based Curriculum," Teaching and Learning in Nursing 12, no. 2 (2017): 95-102.

${ }^{13}$ Charles I. Abramson, "Problems of teaching the behaviorist perspective in the cognitive revolution," Behavioral Sciences 3, no. 1 (2013): 55-71

${ }^{14}$ Beth Sulzer-Azaroff, "The Shaping of Behaviorists: B.F. Skinner's Influential Paper on Teaching Machines," European Journal of Behavior Analysis 5, no. 2 (2004): 129-35.

${ }_{15}$ Martin East, "Research into practice: The task-based approach to instructed second language acquisition," Language Teaching 50, no. 3 (2017): 412-24.

${ }^{16}$ Asmaa Al-Ghamdi, "Building a Positive Environment in Classrooms through Feedback and Praise," English Language Teaching 10, no. 6 (2017): 37.

17 Stephen D. Krashen, "The Din in the Head, Input, and the Language Acquisition Device," Foreign Language Annals 16, no. 1 (1983): 41-44.

18 Christa Van Der Walt dan Nanda Klapwijk, "Language Of Learning And Teaching In A Multilingual School Environment: What Do Teachers Think," Language Matters 46, no. 2 (2015): 293-318, 
acquisition tool that allows the child to develop hypotheses about the language structure obtained ${ }^{19}$. The system of the language is composed of the child involuntarily and then tried in its language use ${ }^{20}$. The language acquired by the child will be continuously tested for validity on the language that is collected by the child while he hears and speaks ${ }^{21}$. Therefore, a series of obtained speeches will be changed and adjusted based on the correct language structure ${ }^{22}$. The concept of nativism is known that the child's environment strongly influences language proficiency in children. The language environment which is adjusted well can deliver the child acquires language skills maximally.

Based on the two theoretical concepts above, it is known that the success of language teaching is primarily determined by the stimulus that is designed by the teacher in the learning process. The trigger can be in using strategies and learning media that are relevant, engaging, and fun. The stimulus can also be in the form of teaching materials that are appropriate to students' needs as well as reinforcement that the teachers give during the learning process. The stimulus provided by the teacher will create a positive response to the students in learning. Besides stimulus-response, the success of language learning is determined by the learning environment. The language environment, which is created by the teacher, can facilitate students in acquiring the language.

\section{Animation Video Technology}

Learning media is a tool that helps teachers delivers learning materials to students; one of the effective media in learning is the technology of animated video ${ }^{23}$. Animation video technology is one of the visualization media that can describe the movement. It consists of a set of objects arranged according to the objectives related to the duration of time. The item in question can be in the form of images of people, animals, plants and buildings, and so forth ${ }^{24}$. Animation video technology is the result of hand painting that is computerized into motion pictures ${ }^{25}$. Animation Video technology is the design of media that produces motion and sound and remarkable life and contains the learning messages. Learning using video technology animation is usually held in the classroom with the appropriate device such as LCD, laptop, a compatible audio system such as a sound system.

The technology of animation video can explain a difficult concept or process and has the power to entertain. An attractive appearance will motivate users to engage in

19 Stephen D. Krashen, “the 'Fundamental Pedagogical Principle' in Second Language Teaching," Studia Linguistica 35, no. 1-2 (1981): 50-70.

${ }^{20}$ Deborah Dubiner, "Second language learning and teaching: From theory to a practical checklist," TESOL Journal 10, no. 2 (2019): 1-17.

21 Yuko Goto Butler, "Second Language Learners' Theories on the Use of English Articles," Studies in Second Language Acquisition 24, no. 3 (2002): 451-80

22 Jan H. Hulstijn, "What Does the Impact of Frequency Tell Us About the Language Acquisition Device?," Studies in Second Language Acquisition 24, no. 2 (2002): 269-73.

${ }^{23} \mathrm{Li}$ Chu Tien, Chei Chang Chiou, dan Yueh Shian Lee, "Emotional design in multimedia learning: Effects of multidimensional concept maps and animation on affect and learning," Eurasia Journal of Mathematics, Science and Technology Education 14, no. 12 (2018).

24 Burn, "Making machinima: animation, games, and multimodal participation in the media arts."

25 Mine Munyofu dkk., "The effect of different chunking strategies in complementing animated instruction," Learning, Media and Technology 32, no. 4 (2007): 407-19. 
the learning process ${ }^{26}$. It is confirmed in the research of De Leeuw \& Van Der Laan that the technology of video animation provides one of the narrative text stories by using colorful images, moving images, and scripts that stimulate interest for the user ${ }^{27}$. The utilization of animation video technology in the learning aims at the optimization of the visual effects. It stimulates students' interaction sustainably that increase their knowledge and skills ${ }^{28}$. The characteristics of animation video technology can explain complicated material in the form of pictures and words, so it helps in conveying the complex material visually and dynamically ${ }^{29}$. Besides, animation video technology can easily attract students' attention because animation offers visual more fun. Animation video technology can stimulate the students' concentration and increase the motivation to learn ${ }^{30}$.

\section{The Theoretical Framework of the Research}

The study is carried out based on the problems faced by the students of primary school in learning the Arabic language. Students experience difficulties in terms of linguistic and non-linguistic. In terms of the language problem, students' difficulties are in the understanding of vocabulary, grammar, knowledge of texts, listening, and speaking. Besides, on the non-linguistic aspect, the problem faced is the process of learning that has not been supported, such as the utilization of exciting learning media and technology. One of the exciting learning media and technologies is the technology of video animation. With the learning media in the form of animation video technology that appeals to elementary school students, it can bring a positive attitude and a mastery of Arabic better.
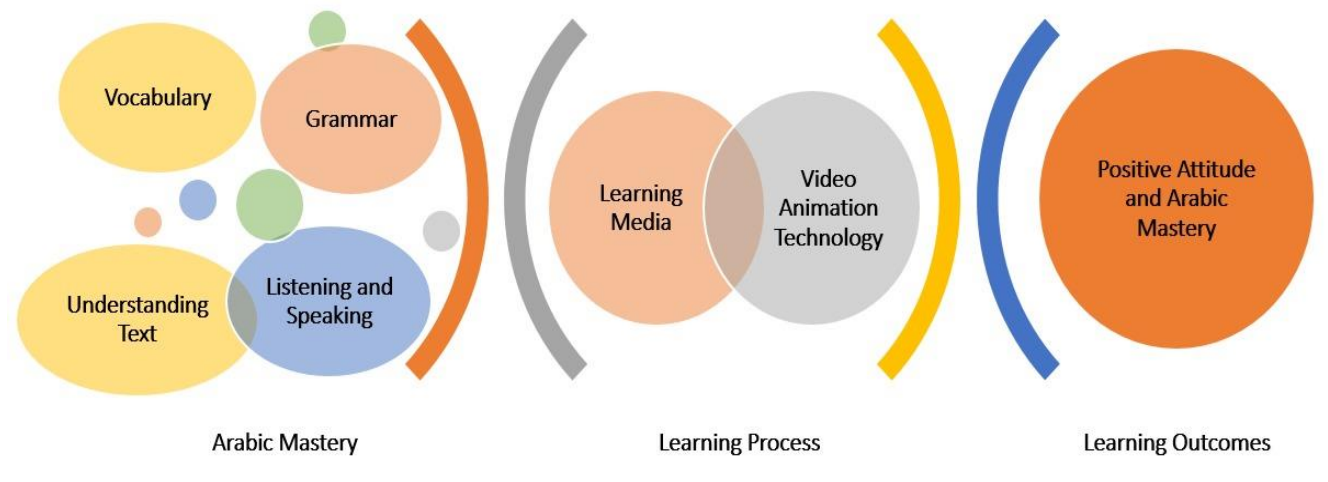

Figure 1. The Research Conceptual Framework

26 Ercan Akpinar, "The use of interactive computer animations based on POE as a presentation tool in primary science teaching," Journal of Science Education and Technology 23, no. 4 (2014): 527-37.

27 Rebecca N.H. de Leeuw dan Christa A. van der Laan, "Helping behavior in Disney animated movies and children's helping behavior in the Netherlands," Journal of Children and Media 12, no. 2 (2018): 159-74.

${ }^{28}$ Hiran B. Ekanayake dkk., "Affective realism of animated films in the development of simulation-based tutoring systems," International Journal of Distance Education Technologies 11, no. 2 (2013): 96-109.

29 Sizhe Liao, Junhui Liang, dan Yadan Li, "Application of multimedia animation technology in learning power updating knowledge," Applied Mechanics and Materials 239-240 (2013): 1641-44.

30 Jean Michel Boucheix dan Emmanuel Schneider, "Static and animated presentations in learning dynamic mechanical systems," Learning and Instruction 19, no. 2 (2009): 112-27. 
From this framework, it can be elaborated that the paradigm of thinking about the difficulties of the Arabic language mastery faced by students in learning is not detached from the learning process and the learning media used by the teacher. The utilization of exciting animation video technology in the learning process will then pose a positive attitude and improve the results of Arabic language learning.

The model of this study uses the approach of mixed-method research to test outcomes and the learning process. This study analyzes animation video technology as a medium of learning and the attitude of students' learning while using animation video technology. The study will also examine the level of transformation ability of students' Arabic language after using animation video technology. The implementation of the research method with the mixed-method research approach is focused on collecting data, analyzing the data, and interpreting the data that is done in a series of studies.

Respondents in the study are the fifth-grade students of Islamic Elementary 3 of Metro City Lampung, totaling 70 students. The respondents' determination is based on the consideration that this school is a superior Islamic elementary school with complete learning facilities. Besides, this school also has professional teachers. Moreover, on the other hand, students experience difficulties in learning Arabic. The respondents' selection is made randomly to the respondents who have the same characteristics in terms of the Arabic language's ability. Besides students, teachers of Arabic are also to be respondents in this study.

Table 1. The Demographics of Respondents

\begin{tabular}{llcccc}
\hline \multicolumn{2}{c}{ Demographics } & \multicolumn{2}{c}{ MIN 3 Metro } & Total & Percentage \\
\hline Class & & V A & V B & 70 & $100 \%$ \\
\hline \multirow{2}{*}{ Gender } & Male & 13 & 18 & 31 & $44.29 \%$ \\
\cline { 2 - 6 } & Female & 22 & 17 & 39 & $55.71 \%$ \\
\hline \multirow{2}{*}{ Ethnics } & $10^{\text {th }}$ & 8 & 6 & 14 & $20 \%$ \\
\cline { 2 - 6 } & $11^{\text {th }}$ & 27 & 29 & 56 & $80 \%$ \\
\cline { 2 - 6 } & Lampung & 10 & 12 & 22 & $31.43 \%$ \\
\cline { 2 - 6 } & Javanese & 15 & 15 & 30 & $42.86 \%$ \\
\cline { 2 - 6 } & Sundanese & 3 & 2 & 5 & $7.14 \%$ \\
\hline \multirow{2}{*}{ Fasility } & Minangkabau & 4 & 2 & 6 & $8.57 \%$ \\
\cline { 2 - 6 } & Palembang & 3 & 4 & 7 & $10 \%$ \\
\cline { 2 - 6 } & Media Audiovisual & $\sqrt{ }$ & $\sqrt{ }$ & $\sqrt{ }$ & $\sqrt{ }$ \\
\cline { 2 - 6 } & LCD & $\sqrt{ }$ & $\sqrt{ }$ & $\sqrt{ }$ & $\sqrt{ }$ \\
\hline
\end{tabular}

The data above explains that the samples taken are the students of class V, which consists of a male and a female, with the age of 10 to 11 years. All respondents have the facilities of adequate instructional media to support learning. The research respondents are from various tribes such as Lampung, Javanese, Sundanese, Minangkabau, and Palembang. The sample on class VA is conducted Arabic learning with the card media and selection on the class VB is carried out Arabic language learning with technology video animation.

Data collection techniques used in this research are interviews, questionnaires, and tests. Interview technique was used to collect data related to the use of animated video in teaching the Arabic language. Interviews were conducted by the researcher with the respondents directly. Interview questions consist of 20 questions developed 
based on indicators of the implementation of learning with video animation. The following table is the interview guide used.

Table 2. The Blueprint of the Interview Guide

\begin{tabular}{clcc}
\hline No & \multicolumn{1}{c}{ Indicator } & Item Number & Total of item \\
\hline 1 & Material delivery & $1,2,3$ & 3 \\
\hline 2 & The clarity of material & $4,5,6,7,8,9$ & 6 \\
\hline 3 & Animation design & $10,11,12,13$ & 4 \\
\hline 4 & Attractiveness & $14,15,16,17$ & 4 \\
\hline 5 & Learning Outcome Evaluation & $18,19,20$ & 3 \\
\hline
\end{tabular}

Furthermore, questionnaire method was used to collect data about students' attitudes in learning the Arabic language by using an animated video. Questionnaire method of students' attitudes consists of 20 items developed based on positive attitude indicators. The following blueprint is used in developing the questionnaire of students' attitudes.

Table 3. The Questionnaire Blueprint of Students' Attitude

\begin{tabular}{|c|c|c|c|c|c|}
\hline No & Indicator & Scale & Score & Item Number & $\begin{array}{c}\text { Total } \\
\text { of Item }\end{array}$ \\
\hline 1 & Tendency & \multirow{3}{*}{$\begin{array}{l}\text { - Better } \\
\text { - Good } \\
\text { - Enough } \\
\text { - Bad } \\
\text { - So Bad }\end{array}$} & \multirow{2}{*}{$\begin{array}{l}5 \\
4 \\
3\end{array}$} & $1,2,3,4,5,6$ & 6 \\
\hline 2 & Motivation & & & $7,8,9,10,11,12,13,14$ & 8 \\
\hline 3 & Self-Concept & & $\begin{array}{l}3 \\
2 \\
1\end{array}$ & $15,16,17,18,19,20$ & 6 \\
\hline
\end{tabular}

The test method was used to collect data about the students' Arabic language ability. It consists of 40 items in the form of multiple choices. The test is developed based on the indicator of students' Arabic language ability. Below is the guideline used in developing the test of the Arabic language skills.

Table 4. Test Instrument Guideline

\begin{tabular}{|c|c|c|c|c|c|}
\hline \multirow{2}{*}{ No } & \multirow{2}{*}{ Indicator } & \multirow{2}{*}{ Item Number } & \multirow{2}{*}{$\begin{array}{c}\text { Total } \\
\text { of Item }\end{array}$} & \multicolumn{2}{|c|}{ Score } \\
\hline & & & & True & False \\
\hline 1 & Vocabulary & $1,2,3,4,5,6,7,8$ & 8 & \multirow{6}{*}{1} & \multirow{6}{*}{0} \\
\hline 2 & Grammar & $\begin{array}{c}9,10,11,12,13,14,15 \\
16,\end{array}$ & 8 & & \\
\hline 3 & Conversation skills & $\begin{array}{c}17,18,19,20,21,22 \\
23\end{array}$ & 7 & & \\
\hline 4 & Reading skills & $\begin{array}{c}24,25,26,27,28,29 \\
30,31,32\end{array}$ & 9 & & \\
\hline 5 & Listening skills & $\begin{array}{c}33,34,35,36,37,38 \\
39,40\end{array}$ & 8 & & \\
\hline \multicolumn{3}{|c|}{ Overall Score } & 40 & & \\
\hline
\end{tabular}

The blueprint table above explains that students' scores are converted into grades using the following formula.

$$
\text { Value }=\frac{\text { Students'score }^{\prime}}{\text { Maximum score }} \times 100
$$


All the instruments used in this study have tested the content validity. The validity test is done by expert judgment and has met the valid criteria. The reliability test is done by using Alpha Cronbach. Here are the results of the test of the content validity and the instrument reliability test.

Table 5. The results of the Validity and Reliability Test of Research Instruments

\begin{tabular}{ccccc}
\hline \multirow{2}{*}{ No } & Instrument & Validity & \multicolumn{2}{c}{ Reliability } \\
\cline { 4 - 5 } & & $\begin{array}{c}\text { Cronbach's } \\
\text { Alpha }\end{array}$ & Total of Item \\
\hline 1 & Interview Guideline & Valid & - & 15 \\
\hline 2 & Questionnaire & Valid & 0,79 & 20 \\
\hline 3 & Test & Valid & 0,82 & 40 \\
\hline
\end{tabular}

Based on the validity and reliability test results above, it explains that all the instruments used are valid and reliable to collect the research data. After validty and realibility test were conducted, the normality test with Kolmogorov-Smirnov' statistic test was also examined at the significant level $\alpha=5 \%$. Meanwhile, the homogeneity test of with Levene's statistic test was examined at the significant level: $\alpha=5 \%$. If the result of prerequisite test shows that samples are from the population of normal distribution and the population variance is homogeneous, data can be examined by the hypothesis test with parametric statistic, which is t-test.

\section{E. The Use of Animation Video in Arabic Language Teaching}

The Arabic language learning in Islamic elementary school has been ongoing using the video animation for 25 minutes on each lesson. The lesson begins with a brief explanation from the teacher about learning goals, providing motivation, and describing the rules that students must adhere to during the video. Students watch a video by taking note of the things that are captured or considered important from the students' perspective. When performing the animation video, the teacher showed and noted students' various reactions, both positive and negative reactions. Through this way, the teacher can analyze activity that will be used as a basis in the evaluation of the Arabic learning process.

Students' activities during the process of using animation videos are by paying attention carefully to the broadcast, paying attention to the flow of the story, noting the storyline, expressing information that is understood from the impressions orally and in writing. Teachers take note of the daily observation, which contains the records of the activities of the students. The observation results showed that $69 \%$ of students concentrated high, measured from the students' attitude, their attention to the screen slides, and activeness in taking note of the storyline. The ability of students to express stories both orally and in writing are also considered. As much as $22 \%$ of students have a medium concentration level, which is characterized by often looking right and left even though they still note the storyline and express the story's flow orally. As much as $9 \%$ of students do not concentrate. They tend to miss the traces of the information, although they pay attention to the screen slides. They do not take note, cannot express the story's flow both orally and in writing, and mutually interfered with one another.

The use of video animation as a medium of learning concludes with an evaluation done by the teacher. The evaluation process is based not only on the teacher's observations during the learning process but also on a language proficiency test, including mastery of vocabulary, ability to express ideas through conversation, reading skills, and grammar. 


\section{F. The Students' Learning Attitude When Using Animation Video Technology}

Learning attitude is an essential factor in the success of the students' learning process. The attitude of learning is characterized by the dimensions of tendency, motivation, and self-concept. The analysis results of students' positive attitude in learning before using the animation video are low, with an average value of 55.27. The students' average positive attitude value after using the animation video is 67.49 .

The Avarage Value of Students' Positive Attitude

$\square$ Before VA $\square$ Before VB $\square$ After VA $\square$ After VB

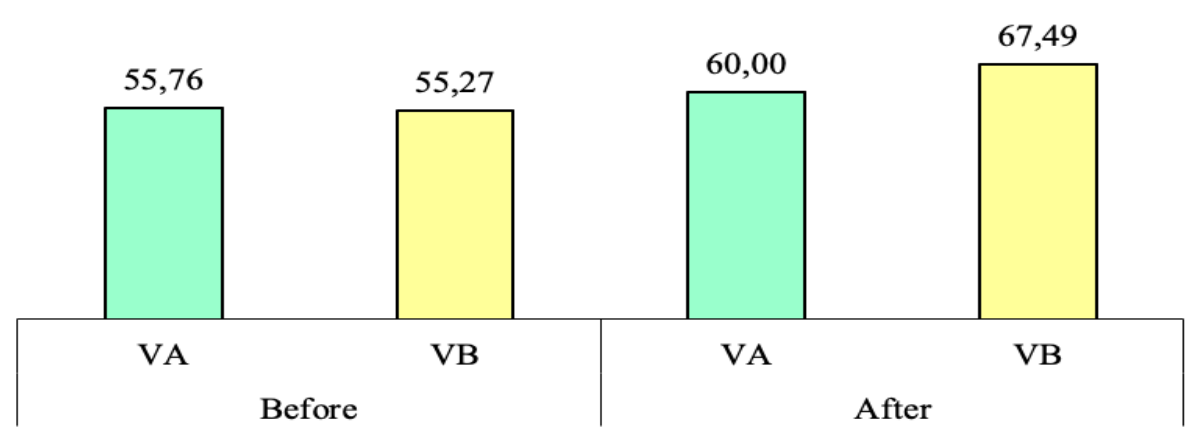

Figure 2. The Avarage of Students' Positive Learning Attitude before and after Using Animation Video

The figure above describes that the value of a students' positive attitude during learning has increased. In grade VA, the lesson conducted using a card media is obtained that the value of attitude before and after learning with the card media in a row is 55.76 and 60.00. Next, the learning in the class VB is performed by using the technology of video animation. It obtains the value of attitude before and after learning with animation video technology in a row is 55.27 and 67.49. Those values indicate that the increase in students' positive attitude in class VA is $8 \%$ and class VB is $22 \%$. Therefore, the increased percentage of students' positive attitude in learning Arabic is higher than learning by using animation video. Below is the chart of the increase in students' positive attitude in learning the Arabic language.

The increased percentage of students' positive attitude value

$\square \mathrm{VA} \square \mathrm{VB}$

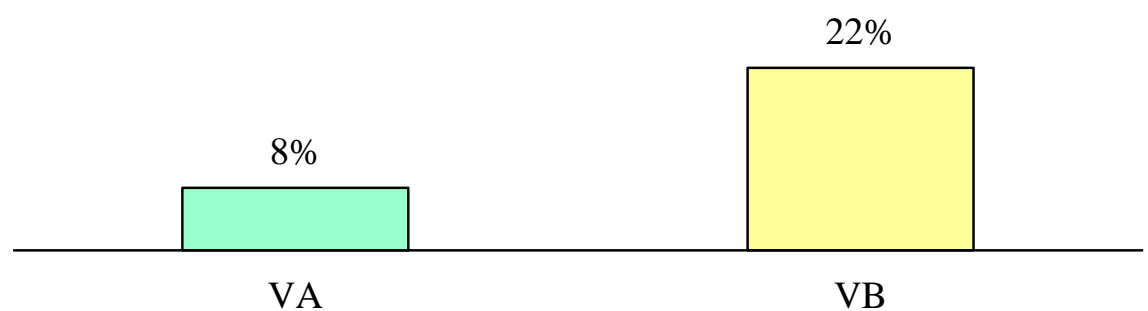

Figure 3. The increased percentage of students' positive attitude value

The tendency of positive attitudes is indicated by students in the form of the willingness to follow all the teacher's learning processes. The students' positive trend is also shown by responding with a sense of fun when learning occurs. Students' enthusiastic behaviour indicates the feeling of pleasure in the retelling of the knowledge gained from animation videos. Besides, the student shows a commitment 
marked with the willingness to do any task given by the teachers under the time provided. Some students showed negative trends in learning. Negative trends revealed in the form of no concentration during the animation video takes place, indifferent attitude to the assigned tasks, not paying attention to the teacher's instructions and not doing the chores. The analysis results show that $91.43 \%$ of students show a positive attitude tendency in learning, and as much as $8.57 \%$ of the students show negative attitudes in learning. Here is the chart result of the increase in the students' positive attitude tendency during learning.

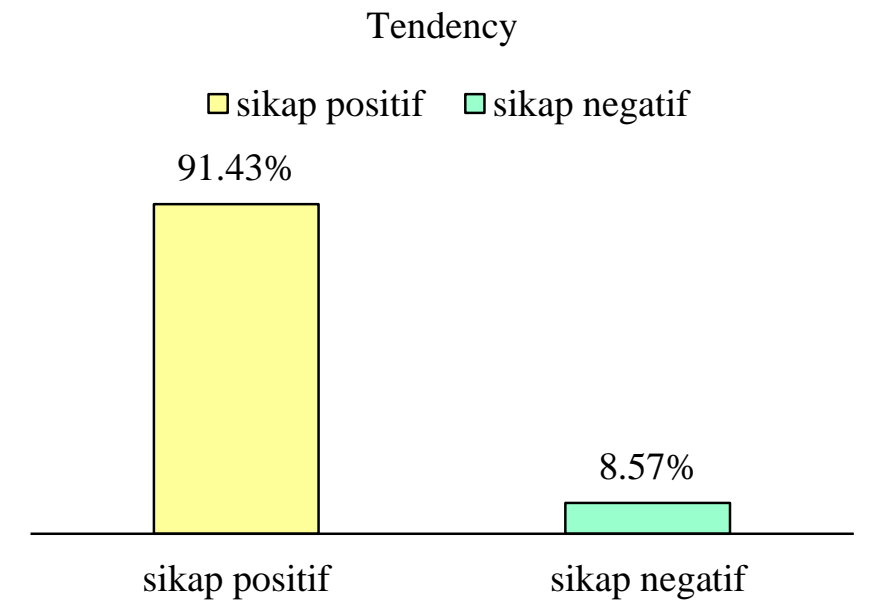

Figure 4. The Percentage of the Students' Positive Attitude Tendency

Students' learning attitudes are also shown in the dimensions of motivation in learning. High motivation is characterized by high concentration, spirit, enthusiasm, obedience to the rules, and doing the task. As much as $62 \%$ of students have very high motivation, $16 \%$ of students have a high motivation, $15 \%$ of students have motivation, and about $7 \%$ have low motivation. Students who have high motivation show a positive attitude in learning, while students who have low motivation showed a negative attitude in learning.

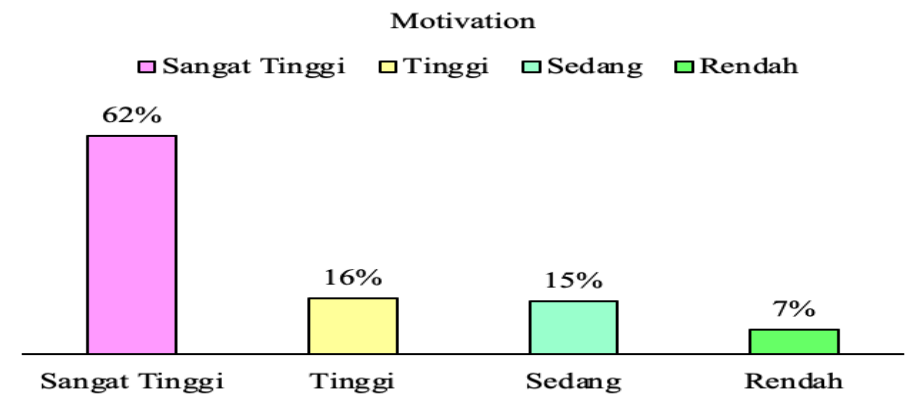

Figure 5. The percentage of Students ' Motivation in Learning Arabic

The attitude of students' learning in the form of self-concept is shown in their efforts to enhance their ability. Teachers provide the learning experience in the aspect of mastery of vocabulary, grammar, speaking, and reading from the self-concept in each student. The learning experience that was difficult at first become easy in understanding every concept learned. It is evident from the way students watching the animation presented in the learning. During the process of watching an animation video, students are very concentrated and follow the storyline carefully. After watching the video animation, students are very excited to retell what they had seen 
and heard from the video animation. The self-concept of students obtained from learning environments that are conditioned by teachers during the learning process takes place. The ability to speak Arabic is obtained from a learning environment prepared by the teachers to have a self-concept in students that continues to grow in line with the increasing of the Arabic language ability achieved by each student. The measurement of the students' positive attitude in learning uses a Likert scale with 5 class intervals, i.e., very low, low, medium, high, and very high with the interval value of 1-100. In the first chart, it can be seen that the average value of students' positive attitude in learning before using the technology of animation video is in the range of the interval 41-60 at medium level and after using the technology of animation video is in the range 61-80.

Table 6. The Scale of Measuring Attitude

\begin{tabular}{cc}
\hline Interval & The Level Of Attitude \\
\hline $1-20$ & Very Low \\
$21-40$ & Low \\
$41-60$ & Enough \\
$61-80$ & High \\
$81-100$ & Very High \\
\hline
\end{tabular}

The use of animation video technology in Arabic language learning can change students' attitudes from a negative mindset into a positive attitude. The Aspects of entertainment in the animation video has been encouraging students to have a high concentration. An exciting storyline encourages students to heed the impressions of animation video from start to finish. While watching the animation video, the students concentrate fully and enthusiastically on each story's notes. After watching the animation video, the students were excited to do the assignment given. This condition is an indicator of the positive attitude of the students. The results of the statistics calculation show that the percentage increases $22 \%$ in the students' positive attitude in learning the Arabic language by using video technology animation. Other factors also determine the growth of the student' positive attitude in learning, such as learning methods and teaching materials.

\section{G. The Influence of the Use of Animation Video to the Mastery of the Arabic language}

The use of animation video technology in the learning of the Arabic language can transform students' ability to speak Arabic and increase the students' positive attitude significantly. The mastery of the Arabic language for students before using video technology animation is still low. Here is the value of students' Arabic language mastery before and after the use of animation video technology.

Table 7. The value of the Mastery of Arabic Language Before and After Learning

\begin{tabular}{cccc}
\hline Class & Media & Before & After \\
\hline V A & Media Card & 54.29 & 68.69 \\
V B & Technology of Animation Video & 53.80 & 77.46 \\
\hline
\end{tabular}

From the data above, it can be explained that learning with a media card and an animation video can improve the mastery of the Arabic language for students. In the class that uses media cards, the value of mastery of the Arabic language earlier is 54.29, and after learning is 68.69. The class that uses animation video technology before 
learning shows the value of 53.80, and after learning displays the value of 77.46. It shows that the increase in the value of the mastery of the Arabic language in the classroom using animation video technology is higher than learning with media cards.

The learning process that uses video animation technology facilitates the students in understanding the subject matter optimally. New vocabulary is quickly understood because the students hear and see how the wording is pronounced. Students can also practice an existing conversation on video animation and practice in simple conversations with peers. The ability of students' grammar is also good because after watching the animation video, students are guided to practice and re-write what is heard by the Arabic language rules. Students' overall competence as the result of the use of animated video in teaching and learning are formulated as learning outcomes. The analysis results of the test data on students show the increase in learning outcomes significantly. To determine whether animation video technology in Arabic learning can transform students' Arabic language skills, the t-test is carried out. Before the t-test is carried out, the data collected is subjected to a prerequisite test, namely the normality and the homogeneity test.

The results of the normality test with statistics of the Kolmogorov-Smirnov's test at the significant level is $\alpha=5 \%=0.05$. It is known that the value of the sig count from the value before and after the learning respectively is $0.156,0.170,0.166$ and 0.160 . The decision of test based on the output of the normality test is obtained the entire value of the sig count is $>\mathrm{a}$, so $\mathrm{H}_{0}$ is accepted. The conclusion of sample normality test comes from a population with a normal distribution. Thus, it can be said that the data is worth tested further.

Then, the homogeneity test is performed with the statistics of Levene's test with a significant level: $a=5 \%=0.05$. It is known that sig count is $0.092>a$, so $\mathrm{H}_{0}$ is accepted. It means that the variance of the population is homogeneous. Based on the prerequisites test carried out, the sample comes from a population that is normally distributed, and the variance of the population is homogeneous. It means that post-test data can be performed for the hypothesis test with the parametrical statistics, that is the t-test. The result of the t-test is: $\alpha=5 \%=0.05$ with criteria of the test results: if sig count is $>\mathrm{a}$, then $\mathrm{H}_{0}$ is accepted. From table 8, it is known that the value of sig (2tailed) count is 0.019 with the test value decision of sig count is $<a$, so $\mathrm{H} 0$ is rejected, and it accepts H1. This result means that the use of technology of animation video in Arabic language learning can transform students' Arabic language ability.

Table 8. T-Test results Influence on the Use of Animation Video Technology toward Learning Outcomes.

Independent Samples Test

\begin{tabular}{cc}
\hline L evene's & \\
Test for & \\
Equality & of \\
Variances & t-test for Equality of Means \\
\hline & $\begin{array}{c}95 \% \text { Confidence } \\
\text { Interval of the } \\
\text { Difference }\end{array}$
\end{tabular}
F Sig. $t \quad d f$
Sig. (2- Mean Std. Error
tailed) Difference Difference Lower Upper 
Value Equal variances $3.618 .061-2.406$ 68

.019

Equal variances not assumed

This research shows several findings. First, students' learning difficulty is in the form of low motivation, and negative attitudes in learning can be overcome with the use of video technology animation. The use of animation video technology in education has facilitated students in the learning process. It is because animation video technology provides a learning space with a touch of entertainment for students. The use of entertaining animation videos has created a sense of fun and stimulates curiosity in the student. A sense of joy in learning makes a high learning tendency in students. This is confirmed in the research of Jansen et al. that the sense of fun and willingness to know an object has increased the concentration and enthusiasm of students for learning. The spirit of learning creates students' positive attitude in learning ${ }^{31}$. Besides, animation video technology has helped students gain proficiency, especially in increasing listening and vocabulary acquisition ${ }^{32}$.

Second, the learning process concerns the achievement of the learning objectives alone and must also consider the role of psychological students stimulated by using dynamic learning media. The psychological condition of the students is characterized by the attitude, either positive or negative attitude. Students' positive attitude in learning is shown in the inclination, motivation, and self-concept that increase significantly. The use of video technology animation has delivered complex and visually dynamic material to understand the material quickly. Besides, engaging animation video technology has created students' tendency to pay attention to any motion that aired. The entertainment aspect in the animation show has motivated students to be active in responding to the learning. This result is in line with Huang et al.'s research that the sense of ease and comfort makes someone feel comfortable and motivated to follow the learning process from start to finish, which then impacts learning objectives ${ }^{33}$.

Third, exciting and fun animation video technology has contributed to improving the mastery of students' Arabic language. The atmosphere of learning using animation video technology has provided a learning atmosphere to relax and entertain, which, in the end, impacts learning outcomes. This evidence is confirmed in Hwang et al. that the atmosphere of learning has impacted the students' psychology in the form of a sense of interest, enthusiasm, and motivation to follow each learning stage. The study,

${ }^{31}$ Malte Jansen dkk., "The dimensional structure of students' self-concept and interest in science depends on course composition," Learning and Instruction 60, no. October 2018 (2019): 20-28,

32 Abdullah S. Aldera dan Mohammed Ali Mohsen, "Annotations in captioned animation: Effects on vocabulary learning and listening skills," Computers and Education 68 (2013): 60-75.

${ }_{33} \mathrm{Yu}$ Chih Huang dkk., "An investigation of motivation and experience in virtual learning environments: a self-determination theory," Education and Information Technologies 24, no. 1 (2019): 591-611. 
which was initially considered very difficult and tedious, turned into a fun process ${ }^{34}$. Besides, the learning success is influenced by the material designed by the teacher in the animation video. The storyline, which is interesting and entertaining, has increased the success of learning. Kubler confirms this study that the material designed excitingly and appropriately with the students' development will help them achieve the learning objectives ${ }^{35}$.

The use of video technology animation as a tool in the learning concludes with an evaluation. The evaluation process is based on the teacher's observations during the use of video technology animation, also on a language proficiency test, which includes mastery of the material heard, speaking ability, reading ability, and grammar. The teacher evaluated to measure the level of success of learning using the technology of animation video. Some research states that the teacher's evaluation process also determines the success of learning 36 .

This study is different from previous studies that see technology only as a tool that helps the teacher explain the subject matter itself. This study is process-oriented learning that emphasizes the role of the positive attitude of students in learning. The analysis also aims to determine the students' language proficiency as the influence of the use of animation video technology used by the teacher. From this study, it is suggested that the Arabic language learning on elementary school students is focused on the design of media-based animation technology that encourages a positive attitude of students in learning and improves the ability to speak.

\section{H. Conclusion}

This study's conclusion shows that what has been said so far about the difficulty in learning the Arabic language and the issue of students' low learning inclinations are not compelling reasons. This study produces findings that video technology animation has stimulated students' positive attitudes in learning. The student's positive attitude has led the enthusiasm, motivation, and earnestness in following the learning process. In addition to the increase in students' positive attitude in learning, Arabic language students' ability has also increased. These abilities include the mastery of listening, vocabulary, reading, and grammar. The use of animation video technology designed with the students' development makes learning more comfortable and fun. The feeling of ease and fun in learning has improved the students' Arabic language mastery.

This study has analyzed the effectiveness of animation video technology in improving students' Arabic language skills at primary school. This study's results can be used by teachers of the Arabic language as alternative media to facilitate the student in learning. This study gives recommendations for further studies related to the use of animated content in Arabic language learning that is relevant to students' age and the

This study's scope is limited to the use of animation video technology in learning the Arabic language for students of elementary school. Therefore, researchers in the

${ }^{34} \mathrm{Wu}$ Yuin Hwang dkk., "Evaluating listening and speaking skills in a mobile gamebased learning environment with situational contexts," Computer Assisted Language Learning 29, no. 4 (2016): 639-57.

35 Cornelius C. Kubler, "Developing course materials for technology-mediated Chinese language learning," Innovation in Language Learning and Teaching 12, no. 1 (2018): 47-55.

${ }^{36}$ Jeffrey S. Nevid dkk., "Classroom Evaluation of Online Quizzing and Concept Building Exercises Embedded in an Integrated Learning System," Psychology Learning and Teaching 19, no. 2 (2020): 184-93; Shirley Murray, Kimberly Laurent, dan Jo Anna Gontarz, "Evaluation of a concept-based curriculum: A tool and process," Teaching and Learning in Nursing 10, no. 4 (2015): $169-75$. 
field of education can do further research with the material and different levels of education to increase the breadth of science knowledge, especially about the theory of the use of animation video technology in the learning process.

\section{Acknowledgments}

This study is supported by the State Elementary School of Metro City leader, along with the Arabic teacher and the students. Without their support, this study would not be possible. Thus, we extend our gratitude to all those who have collaborated in collecting data. This research is also supported by the education foundation of Al-Imam of East Lampung with Grant number 73 in 2019 dated July 22, 2019.

\section{REFERENCES}

Abdul Hakim, Muhammad Kamal bin. "Multimedia and Critical Thinking on Arabic Guided Writing Learning." Dinamika Ilmu 19, no. 2 (2019).

Abramson, Charles I. "Problems of teaching the behaviorist perspective in the cognitive revolution." Behavioral Sciences 3, no. 1, (2013).

Akpinar, Ercan. "The use of interactive computer animations based on POE as a presentation tool in primary science teaching." Journal of Science Education and Technology 23, no. 4, (2014).

Aldera, Abdullah S., dan Mohammed Ali Mohsen. "Annotations in captioned animation: Effects on vocabulary learning and listening skills." Computers and Education 68, (2013).

Al-Ghamdi, Asmaa. "Building a Positive Environment in Classrooms through Feedback and Praise." English Language Teaching 10, no. 6, (2017).

Boucheix, Jean Michel, dan Emmanuel Schneider. "Static and animated presentations in learning dynamic mechanical systems." Learning and Instruction 19, no. 2 (2009).

Brito, Natalie H. "Influence of the Home Linguistic Environment on Early Language Development." Policy Insights from the Behavioral and Brain Sciences 4, no. 2 (2017).

Burn, Andrew. "Making machinima: animation, games, and multimodal participation in the media arts." Learning, Media and Technology 41, no. 2 (2016).

Butler, Yuko Goto. "Second Language Learners' Theories on the Use of English Articles." Studies in Second Language Acquisition 24, no. 3 (2002).

Crossley, Scott A. "Technological disruption in foreign language teaching: The rise of simultaneous machine translation." Language Teaching 51, no. 4 (2018).

Dubiner, Deborah. "Second language learning and teaching: From theory to a practical checklist." TESOL Journal 10, no. 2 (2019).

East, Martin. "Research into practice: The task-based approach to instructed second language acquisition." Language Teaching 50, no. 3 (2017).

Ekanayake, Hiran B., Uno Fors, Robert Ramberg, Tom Ziemke, Per Backlund, dan Kamalanath P. Hewagamage. "Affective realism of animated films in the development of simulation-based tutoring systems." International Journal of Distance Education Technologies 11, no. 2 (2013).

Han, Jing, dan Qingsheng Lu. "A Correlation Study among Achievement Motivation, Goal-Setting and L2 Learning Strategy in EFL Context." English Language Teaching 11, no. 2 (2017). 
Han, Zhao Hong. “Task-Based Learning in Task-Based Teaching: Training Teachers of Chinese as a Foreign Language." Annual Review of Applied Linguistics 38 (2018).

Higgins, Bonnie, dan Helen Reid. "Enhancing 'Conceptual Teaching/Learning' in a Concept-Based Curriculum." Teaching and Learning in Nursing 12, no. 2 (2017).

Huang, Yu Chih, Sheila J. Backman, Kenneth F. Backman, Francis A. McGuire, dan De Wayne Moore. "An investigation of motivation and experience in virtual learning environments: a self-determination theory." Education and Information Technologies 24, no. 1 (2019).

Hulstijn, Jan H. "What Does the Impact of Frequency Tell Us About the Language Acquisition Device?" Studies in Second Language Acquisition 24, no. 2 (2002)

Hwang, Wu Yuin, Timothy K. Shih, Zhao Heng Ma, Rustam Shadiev, dan Shu Yu Chen. "Evaluating listening and speaking skills in a mobile game-based learning environment with situational contexts." Computer Assisted Language Learning 29, no. 4 (2016)

Jansen, Malte, Ulrich Schroeders, Oliver Lüdtke, dan Herbert W. Marsh. “The dimensional structure of students' self-concept and interest in science depends on course composition." Learning and Instruction 60, no. October 2018 (2019).

Krashen, Stephen D. "The Din in the Head, Input, and the Language Acquisition Device." Foreign Language Annals 16, no. 1 (1983)

- - - "the 'Fundamental Pedagogical Principle' in Second Language Teaching." Studia Linguistica 35, no. 1-2 (1981)

Kubler, Cornelius C. "Developing course materials for technology-mediated Chinese language learning." Innovation in Language Learning and Teaching 12, no. 1 (2018).

Kung, Fan Wei. "Teaching second language reading comprehension: the effects of classroom materials and reading strategy use." Innovation in Language Learning and Teaching 13, no. 1 (2019).

Latifah, Latifah, dan Nur Aviya. “Pengaruh Model Cooperative Learning Tipe Think Pair Share (TPS) Terhadap Hasil Belajar Siswa pada Pelajaran Bahasa Arab di MI." Al Ibtida: Jurnal Pendidikan Guru MI 5, no. 1 (2018).

Leeuw, Rebecca N.H. de, dan Christa A. van der Laan. "Helping behavior in Disney animated movies and children's helping behavior in the Netherlands." Journal of Children and Media 12, no. 2 (2018).

Liao, Sizhe, Junhui Liang, dan Yadan Li. "Application of multimedia animation technology in learning power updating knowledge." Applied Mechanics and Materials 239-240 (2013).

Maijala, Minna. "Culture teaching methods in foreign language education: pre-service teachers' reported beliefs and practices." Innovation in Language Learning and Teaching 14, no. 2 (2020).

Maredia, Mywish K., Byron Reyes, Malick N. Ba, Clementine L. Dabire, Barry Pittendrigh, dan Julia Bello-Bravo. "Can mobile phone-based animated videos induce learning and technology adoption among low-literate farmers? A field experiment in Burkina Faso." Information Technology for Development 24, no. 3 (2018)

Mason, Andrea, dan Caroline Payant. "Experienced teachers' beliefs and practices toward communicative approaches in teaching English as a foreign language in rural Ukraine." TESOL Journal 10, no. 1 (2019).

Muh Barid Nizarudin Wajdi. "Dynamic Learning for the Arabic language." EDUTEC: Journal of Education And Technology 2, no. 2 (2019).

Munyofu, Mine, William J. Swain, Bradley D. Ausman, Huifen Lin, Khusro Kidwai, dan Francis Dwyer. "The effect of different chunking strategies in 
complementing animated instruction." Learning, Media and Technology 32, no. 4 (2007).

Murray, Shirley, Kimberly Laurent, dan Jo Anna Gontarz. “Evaluation of a conceptbased curriculum: A tool and process." Teaching and Learning in Nursing 10, no. 4 (2015).

Nevid, Jeffrey S., Alexander J. Gordon, Mark D. Terjesen, dan Ashley Hicks. "Classroom Evaluation of Online Quizzing and Concept Building Exercises Embedded in an Integrated Learning System." Psychology Learning and Teaching 19 , no. 2 (2020).

Oxford, Rebecca L. "Language Learning Styles and Strategies-Concepts and Relationships-Oxford2003.Pdf" 41 (2003).

Ruan, Jingjing, dan Jane Medwell. "Using social networking technology to develop intercultural communicative competence: a case of GCSE Mandarin." Innovation in Language Learning and Teaching 0, no. 0 (2019).

Said, Rukman AR. "Fa'aliyyah Isti'mal al-Wasail al-Sam'iyyah wa al-Mar'iyyah li Tanmiyah Maharah al-Istima' fi Ta'lim al-Lugah al-'Arabiyyah bi al-Madrasah alTsanawiyah as-'Adiyah Pengkendekan bi Al-Fashl al-Tsamin fi Luwu alSyimaliyah." AL IBRAH: Journal of Arabic Languange Education, (2018).

Sulzer-Azaroff, Beth. "The Shaping of Behaviorists: B.F. Skinner's Influential Paper on Teaching Machines." European Journal of Behavior Analysis 5, no. 2 (2004).

Tien, Li Chu, Chei Chang Chiou, dan Yueh Shian Lee. "Emotional design in multimedia learning: Effects of multidimensional concept maps and animation on affect and learning." Eurasia Journal of Mathematics, Science and Technology Education 14, no. 12 (2018)..

Walt, Christa Van Der, dan Nanda Klapwijk. "Language Of Learning And Teaching In A Multilingual School Environment: What Do Teachers Think?" Language Matters 46, no. 2 (2015). 